\title{
THE DEVELOPMENT OF ISLAMIC BIG BOOK LEARNING MEDIA FOR EARLY CHILDREN'S LANGUAGES
}

\author{
Juli Maini Sitepu ${ }^{1}$, Mawaddah Nasution ${ }^{2}$, Widya Masitah ${ }^{3}$ \\ Fakultas Agama Islam, Universitas Muhammadiyah Sumatera Utara, Indonesia 1,2,3 \\ julimaini@umsu.ac.id, mawaddahnst@umsu.ac.id, widvamasitah@umsu.ac.id
}

\author{
Received: 08-07-2021 \\ Revised: 20-09-2021 \\ Accepted: 30-10-2021
}

\begin{abstract}
This article aims to develop Big Bookis learning media (Big Book Islami). The problems that occur are the children's language skills are still not optimal and the learning media used by the teacher is less attractive so that they are less able to improve children's language skills. This article uses a research and development approach. The data collection technique used in this research is a questionnaire and documentation method. Media that have been assessed by material experts and teachers are then given to students of Kindergarten ABA 13 Helvetia Medan as respondents and their language development is assessed by the teacher. The method used to analyze the data is expressed in the distribution of scores on a scale of five against a predetermined rating scale category. The results of Islamic Big Book Learning Media Development are declared suitable for use after being tested by developers, material experts, media experts, and users. Details of the data obtained from the test results include: material expert testing obtained a score of 4 and a presentation value of $80 \%$ with a decent category, media expert testing obtained a score of 4 , and a presentation value of $80 \%$ with a decent category, and the results of children's language development through Islamic Big Book 80 media. .83 with a well-developed category. The results of the study show that Big Bookis media can improve children's language skills in Kindergarten ABA 13 Helvetia Medan.
\end{abstract}

Keywords: Learning Media, Islamic Big Book, Early Childhood Language, Research and Developtment

\begin{abstract}
Abstrak
Artikel ini bertujuan untuk mengembangkan media pembelajaran Big Bookis (Big Book. Islami). Adapun masalah yang terjadi adalah kemampuan bahasa anak yang masih belum maksimal dan media pembelajaran yang digunakan guru kurang menarik sehingga kurang mampu meningkatkan kemampuan bahasa anak. Artikel ini menggunakan pendekatan penelitian dan pengembangan (Research and Development). Teknik pengumpulan data yang digunakan dalam penelitian ini adalah metode angket/kuesioner dan dokumentasi. Angket ini digunakan untuk mengumpulkan data tentang kelayakan media pembelajaran yang dibuat yang dinilai oleb abli materi dan abli media kemudian diberikan kepada guru untuk dinilai kevalidan dan kepraktisannya. Media yang telah dinilai abli materi dan guru kemudian diberikan kepada siswa TK ABA 13 Helvetia Medan sebagai responden dan perkembangan bahasanya dinilai oleh guru. Metode yang digunakan untuk menganalisis data diungkapkan dalam distribusi skor skala lima terbadap kategori skala penilaian yang telah ditentukan. Hasil Pengembangan Media Pembelajaran Big Bookis dinyatakan layak digunakan setelah dilakukan pengujian oleh pengembang, abli materi, abli media dan pengguna. Rincian data yang diperoleh dari hasil pengujian antara lain: pengujian abli materi diperoleh skor 4 dan nilai presentasi 80\% dengan kategori layak, pengujian abli media diperoleb skor 4 dan nilai
\end{abstract}


presentasi 80\% dengan kategori layak, dan hasil perkembangan bahasa anak melalui media Big Bookis 80,83 dengan kategori berkembang dengan baik. Hasil penelitian menujukkan bahwa media Big Bookis dapat meningkatkean kemampuan bahasa anak di TK ABA 13 Helvetia Medan.

Kata Kunci : Media Pembelajaran, Big Book Islami, Bahasa Anak. Usia Dini, Riset Pengembangan.

\section{INTRODUCTION}

Development at an early age determines a child's development for the next stage. Early childhood is also known as the golden age, because at this age all aspects of child development will grow and develop very rapidly ${ }^{1}$. There are many aspects that must be developed at an early age, ranging from physical-motor aspects, cognitive aspects, language aspects, socio-emotional aspects, moral aspects of religion. The development of all existing aspects must be stimulated appropriately so that later children can grow and develop optimally according to their age stages ${ }^{2}$.

Language development is closely related to the overall development of children both in terms of cognitive, social, and emotional. As a means of expression, children learn to express the language of their minds through verbal language. Language is the sounds, signs, and meanings that are used to communicate every day ${ }^{3}$. Children's language development includes four aspects, namely aspects of listening/listening, speaking, reading and writing ${ }^{4}$. Children's language skills will be the basis for children's ability to obtain and process information and develop themselves through socialization with their environment.

In the context of learning, early childhood storytelling can be said as an effort to develop the potential of children's language skills through hearing and then retelling them with the aim of training children in conversing to convey ideas in oral form ${ }^{5}$. Storytelling activities make a big contribution to the overall development of children as an implication of their language development, so that children will have the ability to develop other aspects of development with good language skills. ${ }^{6}$

${ }^{1}$ Eka Nurbety and Yuli Kurniawati Sugiyo Pranoto, 'Relationship Between Self Regulation with SelfEsteem of Early Childhood in Kindergarten Islamic Integrated Bina Amal Semarang City', BELIA: Early Childhood Education Papers 7, no. 1 (2018): 26-31; Fauzi Fauzi, Supa'at Supa'at, and Ifada Novikasari, 'HolisticIntegrative Eduaction System in an Islamic Kindergarten', QIJIS (Qudus International Journal of Islamic Studies) 7, no. 2 (30 December 2019): 399, https://doi.org/10.21043/qiiis.v7i2.6449.

2 Nurbety and Pranoto, 'Relationship Between Self Regulation with Self-Esteem of Early Childhood in Kindergarten Islamic Integrated Bina Amal Semarang City'; Okda Firasaty and Henny Puji Astuti, 'The Creativity of Early Childhood Painting through Media Waste in Islamic Center Kindergarten Brebes', BELIA: Early Childhood Education Papers 6, no. 2 (2017): 98-102.

3 Alfitriani Siregar, Ratna Sari Dewi, and Rita Harisma, 'Pengajaran Anak Usia Dini Melalui Buku Flanel Terintegrasi Dalam Bahasa Inggris’, Paramasastra 5, no. 1 (2018), https://doi.org/10.26740/parama.v5i1.2731.

${ }^{4}$ Putu Indah Lestari Oleh Nita Nurcahyani WS, Elizabeth Prima, 'Kata Bergambar Pada Anak Kelompok B', Meningkatkan Kemampuan Berbahasa Anak. Usia Dini Melalui Permainan Menjepit Kartu Kata Bergambar Pada Anak. Kelompok 1, no. 1 (2016): 48.

${ }^{5}$ Indah Fajrotuz Zahro, 'Meningkatkan Perilaku Prososial Anak Dengan Teknik Islamic Storytelling Finger Doll', Ną̧hruna: Jurnal Pendidikan Islam 1, no. 1 (16 August 2018): 80-95, https://doi.org/10.31538/nzh.v1i1.43.

${ }^{6}$ Widya Masitah and Juli Hastuti, 'Meningkatkan Kemampuan Bahasa Melalui Metode Bercerita Dengan Menggunakan Media Audio Visual Di Kelompok B RA Saidi Turi Kecamatan Pancur Batu Kabupaten Deli Serdang', Intiqad: Jurnal Agama Dan Pendidikan Islam 8, no. 2 (2016): 120-46, https://doi.org/10.30596/intiqad.v8i2.733. 
Developing children's language is very well done when using learning media. Media are forms of communication, both printed and audiovisual and their equipment that can be manipulated, seen, heard and read. so that it can be used to transmit messages from the sender to the recipient and can stimulate the thoughts, feelings, concerns, and interests and concerns of students in such a way that the learning process occurs ${ }^{7}$. In the learning process, the media is a container and distributor of messages from the source of the message (the teacher). ${ }^{8}$

There are several types of learning media, including: ${ }^{9}$ 1) Environmental Media, which is a place or atmosphere (circumstances) that can affect a person's growth and development. This means that environmental media is in the learning process children are introduced or brought to a place that can affect their growth and development. 2) Game media is a medium that is very liked by children. The game is an object that can be used by students as a means of playing in order to develop creativity and all the potential that children have. Game media can be in the form of puzzles, swings, dakon, and so on. The principle in using the game as a learning medium is that the game has an element of security and comfort.

In early childhood, game media is very much needed, because at an early age the way children learn is still learning while playing. Through learning media, the process of playing and learning at school will be more fun and can increase children's enthusiasm for learning. ${ }^{10}$ One of the learning media that can be used is Big book. Big book is a medium that has special characteristics that are raised, both text and images, and has special characteristics in terms of image shape and color. ${ }^{11}$ Big books are also picture books that are very large in size and are used by teachers in reading together. ${ }^{12}$ Big Book is a visual learning media that has four functions according to Levie \& Lentz, namely affective function, affective function, cognitive function, and compensatory function. ${ }^{13}$

Based on the results of interviews and observations made by researchers, during this pandemic period learning was carried out face-to-face and several days online. Teachers only use story books to develop language in children. In addition, teachers usually only tell a story to children and use the question and answer method in developing children's language. The story books used by the teacher are also only small story books. So that only the teacher can see and read it. This makes children very bored, even many children who do not listen to their teachers, but prefer to play and annoy their friends. Likewise with the ability of teachers in making learning media. Usually teachers only use learning media available at schools such as educational props, reading books and story books. Even though teachers should be able to

\footnotetext{
${ }^{7}$ Juli Maini Sitepu and Mawaddah Nasution, 'Kreativitas Pembuatan Media Pembelajaran Big Book Pada Guru-Guru RA Di Kecamatan Medan Maimun', JURNAL PRODIKMAS Hasil Pengabdian Kepada Masyarakat 3, no. 1 (2018): 8-16.

${ }^{8}$ Fatikh Inayahtur Rahma, '(Kajian Terhadap Langkah-Langkah Pemilihan Media Dan Implementasinya Dalam Pembelajaran Bagi Anak Sekolah Dasar)', Jurnal Studi Islam 14, no. 2 (2019): 87-99.

${ }^{9}$ Muhammad Fadillah, Desain Pembelajaran PAUD (Yogyakarta: Ar-Ruzz Media, 2012).

10 Widya Masitah, 'Pembuatan Media Pembelajaran Melalui Seni Decaupage Pada Guru Raudhatul Athfal Kecamatan Medan Area' 2, no. 2 (2018).

11 Ivonne Hafidlatil Kiromi and Puji Yanti Fauziah, Jurnal Pendidikan Dan Pemberdayaan Masyarakat Camatan Tolangohula Kabupaten Gorontalo', Jurnal Pendidikan Dan Pemberdayaan Masyarakat 3, no. 4 (2016): 3847.

${ }^{12}$ K Tomkins, G.E \& Hoskisson, Language Arts Content Teaching Strategies (USA: Prentice Hall, Inc, 1995).

13 Azhar Arsyad, Media Pembelajaran (Jakarta: Rajagrafindo Persada., 2011).
} 
make their own learning media so that children don't feel bored with the same learning media. Big book learning media can be purchased or made by the teacher himself. There are many big book learning media available in the market but there is no big book that is very large and has Islamic value.

Therefore, the Islamic big book that is made is a modification of the big book that is often available in the market. The big book Islamic learning media will later contain interesting Islamic stories with large pictures and can attract children's attention so that children can clearly see the writing and pictures in the book. With the Islamic big book, children will get Islamic stories that are designed in an attractive way and teachers can also instill Islamic values in children.

\section{METHOD}

The method used in this study is research and development and the media developed is a learning product in the form of Islamic Big Book learning media. This study uses the Borg and Gall research model developed by Sugiyono which includes 10 stages, namely potential and problem stages, data collection, big bookis media design, big bookis media validation, big bookis media design revision, trials, product revisions, usage trials., product revision, mass production. ${ }^{14}$

However, the researcher only limited this research to the seventh stage, namely the product revision stage. The data collection technique used in this research is the questionnaire and documentation method. The Islamic Big Book media that has been compiled will be validated by experts related to material and media. The instrument used by the researcher to be given to the validator is a questionnaire instrument in the form of a rating scale. The indicators used were adopted from the National Education Standards Agency which were adapted to the needs of the author.

\section{Tabel 1. Product Validation Questionnaire Indicator}

\begin{tabular}{ll}
\hline \multicolumn{1}{c}{ Material Expert } & \multicolumn{1}{c}{ Media Expert } \\
\hline Material suitability & $\begin{array}{l}\text { The physical size of the Islamic Big Book } \\
\text { media }\end{array}$ \\
Material accuracy & Islamic Big Book media skin layout \\
Supporting learning materials & The letters used are attractive and easy to read \\
Material updates & Module cover illustration \\
Islamic values & Layout consistency \\
Presentation technique & Harmonious layout elements \\
Material presentation support & Complete layout elements \\
In accordance with the development of & Layout speeds up understanding \\
students & \\
Comunicative & Simple book content typography \\
Dialogic and Interactive & Easy-to-read typography \\
Conformity with Indonesian language & Typography of the book content makes it \\
rules & easier to understand \\
\hline
\end{tabular}

\footnotetext{
${ }^{14}$ Sugiyono, Metode Penelitian Pendidikan Pendekatan Kuantitatif Kualitatif Dan R\&D (Bandung: Alfabeta, 2014).
} 


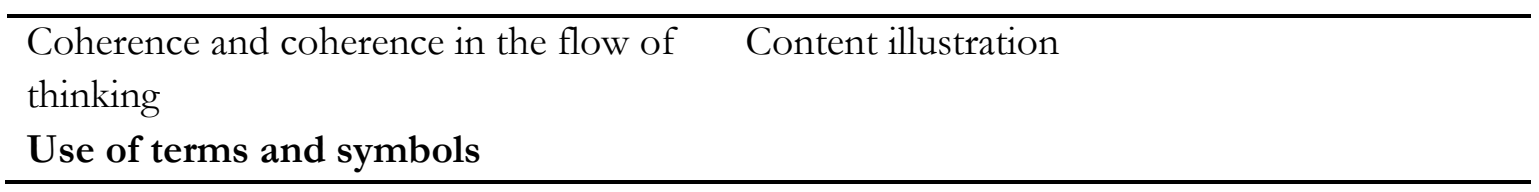

The Islamic Big Book media design that has been validated and has received suggestions and directions by the two validators, will then be used as material for improvement. The revised Islamic Big Book media is then given to the teacher to be tested on students in the classroom.

\section{RESULT AND DISCUSSION}

The Islamic Big Book that was developed is a large book in which there are interesting stories with Islamic nuances supported by large and attractive pictures that can be seen by all children in the class. This Islamic Big Book contains 23 pages with a size of $40 \times 60 \mathrm{~cm}$. The hope is that this Islamic Big Book can motivate early childhood to learn languages such as listening to stories, answering questions, making statements and being able to repeat what the teacher has read in class.

Figure 2 . Fort Cover Islamic Big Book

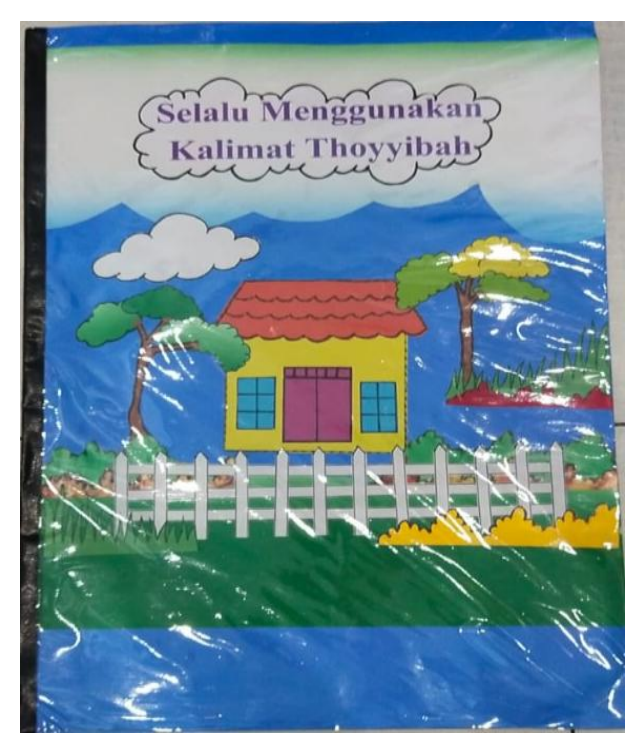

Figure 3. Contents of Islamic Big Book
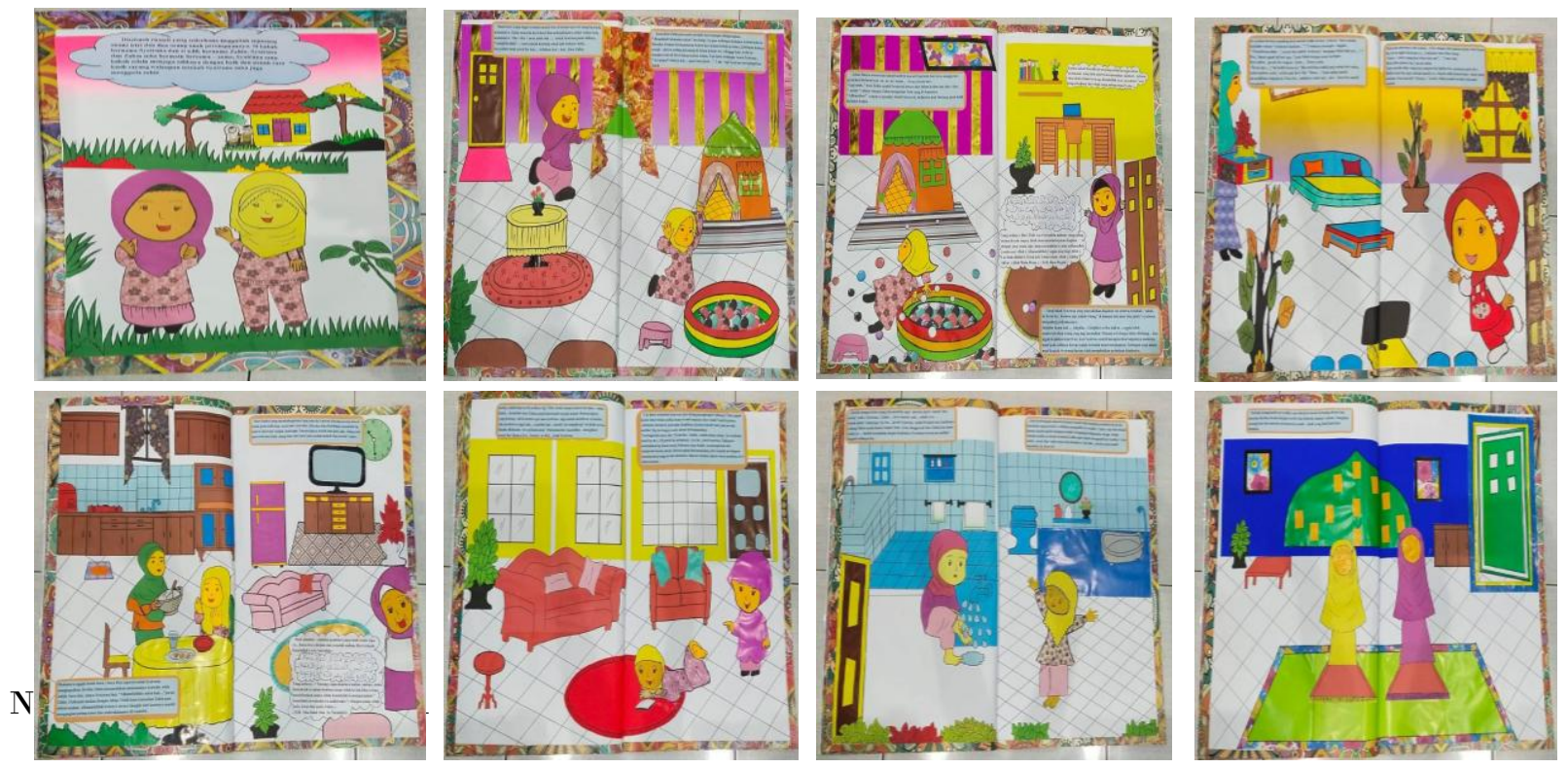

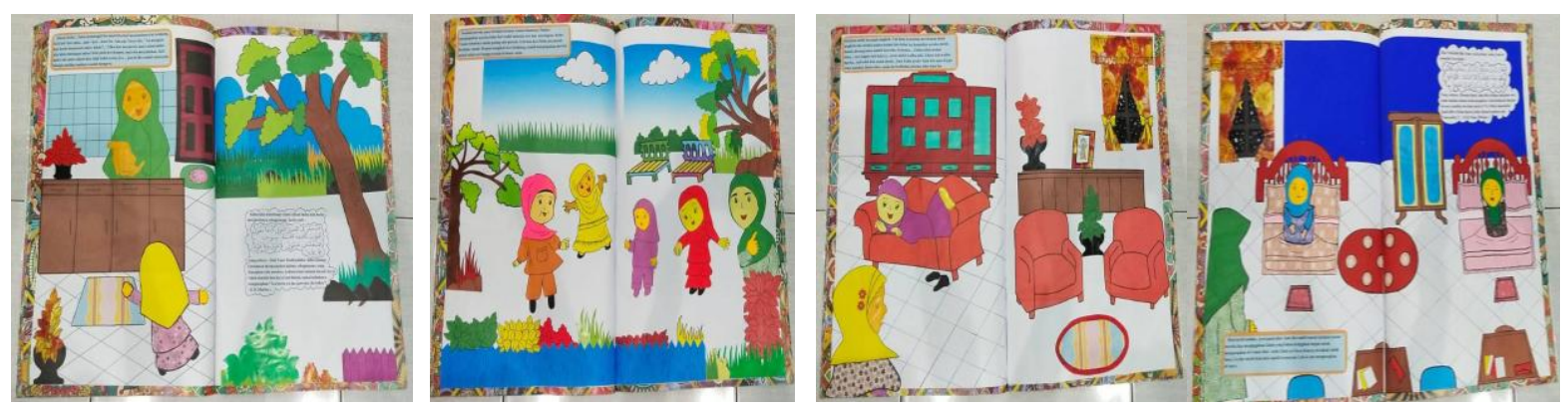

\section{Material Expert Validation}

The validator as a material expert to validate the content of the "Islamic Big Book in this development research is Mrs. Dra. Zuriah, M.Pd. He is a kindergarten teacher at TK ABA 13 Helvetia Medan. Researchers chose him because in addition to teaching at ABA 13 Helvetia Kindergarten, Medan, who daily assists early childhood learning at school, he also has knowledge of the Indonesian language which is capable of assessing the content of Big Bookis products for early childhood. The material expert gave an assessment with an average score of 4 which was included in the appropriate criteria with a presentation value of $80 \%$ of the eligibility.

Tabe1 2. Material Quality Assessment Results from Material Experts

\begin{tabular}{|c|c|c|c|c|c|c|c|}
\hline \multirow[t]{2}{*}{ No. } & \multirow[t]{2}{*}{ Aspek yang Dinilai } & \multicolumn{5}{|c|}{ Rating } & \multirow[t]{2}{*}{ Criteria } \\
\hline & & 1 & 2 & 3 & 4 & 5 & \\
\hline 1. & $\begin{array}{l}\text { The suitability of the material with developmental } \\
\text { aspects }\end{array}$ & & & & $\sqrt{ }$ & & Worthy \\
\hline 2. & The suitability of the material for the child's age & & & & $\sqrt{ }$ & & Worthy \\
\hline 3. & Material accuracy & & & & $\sqrt{ }$ & & Worthy \\
\hline 4. & Support learning materials & & & & $\sqrt{ }$ & & Worthy \\
\hline 5. & Interesting material & & & & $\sqrt{ }$ & & Worthy \\
\hline 6. & The material contains Islamic values & & & & $\sqrt{ }$ & & Worthy \\
\hline 7. & Appropriate material presentation techniques & & & & $\sqrt{ }$ & & Worthy \\
\hline 8. & Pictures according to the content of the material & & & & $\sqrt{ }$ & & Worthy \\
\hline 9. & Communicative material & & & & $\sqrt{ }$ & & Worthy \\
\hline 10. & In accordance with the rules of Indonesian & & & & $\sqrt{ }$ & & Worthy \\
\hline 11. & Coherence of the storyline & & & & $\sqrt{ }$ & & Worthy \\
\hline 12. & Easy language for children to understand & & & & $\sqrt{ }$ & & Worthy \\
\hline 13. & Fill in the material with the appropriate picture & & & & $\sqrt{ }$ & & Worthy \\
\hline & Total & 0 & 0 & 0 & 52 & $\mathbf{0}$ & \\
\hline & Total Score & & & 52 & & & Worthy \\
\hline & Average Score & & & 4 & & & \\
\hline & Presentation & & & $80 \%$ & & & \\
\hline
\end{tabular}




\section{Media Expert Validation}

The media expert who became the validator in this Big Bookis development research is Dr. Hasrian Rudi Setiawan, M.PdI. He is one of the lecturers in the Faculty of Islamic Religion who teaches Media and Learning resources and Graphic Design courses as well as Learning Animation courses. The researcher chose him as a media expert validator because his competence in learning media and learning technology is very qualified. Media experts gave an assessment with an average score of 4 which was included in the appropriate criteria with a presentation value of $80 \%$ of the eligibility.

Tabel 3. Media Quality Assessment Results from Media Experts

\begin{tabular}{|c|c|c|c|c|c|c|c|}
\hline \multirow[t]{2}{*}{ No. } & \multirow[t]{2}{*}{ Rated aspect } & \multicolumn{5}{|c|}{ Rating } & \multirow[t]{2}{*}{ Criteria } \\
\hline & & 1 & 2 & 3 & 4 & 5 & \\
\hline 1. & $\begin{array}{l}\text { Islamic Big Book Media Physical Size 40X60 } \\
\mathrm{cm}\end{array}$ & & & & $\sqrt{ }$ & & Worthy \\
\hline 2. & Interesting Islamic Big Book Media Cover & & & & $\sqrt{ }$ & & Worthy \\
\hline 3. & The letters used are attractive and easy to read & & & & $\sqrt{ }$ & & Worthy \\
\hline 4. & Layout consistency & & & & $\sqrt{ }$ & & Worthy \\
\hline 5. & Suitability of image layout elements & & & & $\sqrt{ }$ & & Worthy \\
\hline 6. & $\begin{array}{l}\text { The suitability of the elements of writing with } \\
\text { pictures }\end{array}$ & & & & $\sqrt{ }$ & & Worthy \\
\hline 7. & Full image and text layout & & & & $\sqrt{ }$ & & Worthy \\
\hline 8. & Consistent image and text layout & & & & $\sqrt{ }$ & & Worthy \\
\hline 9. & $\begin{array}{l}\text { Big Book pictures are interesting and } \\
\text { appropriate }\end{array}$ & & & & $\sqrt{ }$ & & Worthy \\
\hline 10. & Islamic Big Book images are easy to understand & & & & $\sqrt{ }$ & & Worthy \\
\hline 11. & Simple Islamic Big Book content typography & & & & $\sqrt{ }$ & & Worthy \\
\hline 12. & $\begin{array}{l}\text { The typography of the contents of the Islamic } \\
\text { Big Book is easy to understand }\end{array}$ & & & & $\sqrt{ }$ & & Worthy \\
\hline 13. & $\begin{array}{l}\text { The color of the Islamic Big Book image is } \\
\text { appropriate and attractive }\end{array}$ & & & & $\sqrt{ }$ & & Worthy \\
\hline & Total & 0 & 0 & 0 & 52 & 0 & \\
\hline & Total Skor & & & 52 & & & Worthy \\
\hline & Average Skor & & & 4 & & & \\
\hline & Presentation & & & $80^{\circ}$ & & & \\
\hline
\end{tabular}

\section{Small-Scale Trial of Islamic Big Book Media}

After the Islamic Big Book learning media product developed was validated by material experts and media experts, then this product was tested on students at ABA 13 Helvetia Kindergarten, Medan. This trial was carried out with the aim of seeing children's language development through the use of Big Bookis learning media. From the Big Bookis media trial, it is possible to find out how much the feasibility value of the product being developed is. The Big Bookis media trial was carried out by the classroom teacher, then the child development assessment was carried out by the accompanying teacher. Children's language development is 
assessed through 12 statement items made based on the language skills of children aged 4-6 years according to Permendiknas No 58 of 2009 concerning PAUD standards, namely the ability to receive language and the ability to express language. Respondents of the trial amounted to six students.

\begin{tabular}{|c|c|c|}
\hline Respondent & Skor (X) & $(\mathrm{Y})$ \\
\hline 1 & 48 & 60 \\
\hline 2 & 48 & 60 \\
\hline 3 & 48 & 60 \\
\hline 4 & 48 & 60 \\
\hline 5 & 49 & 60 \\
\hline 6 & 49 & 60 \\
\hline Amount & 49 & 360 \\
\hline Average & 291 & 60 \\
\hline Presentation & 48,5 & 80,83 \\
\hline
\end{tabular}

Based on the table above, it can be seen that the average score obtained by children at the small-scale trial stage is 48.5 with a presentation of $80.83 \%$. This proves that the Big Bookis media that has been developed can improve language skills in early childhood.

\section{CONCLUSSION}

Based on the results of the research that has been done, it can be concluded that: 1) The Islamic Big Book learning media developed has met the valid criteria as evidenced by the average validity results of media experts and material experts with a score of 4 , which means the criteria are valid with a presentation value of $80 \%$ and Big Bookis media declared eligible. 2) The developed Islamic Big Book learning media has improved the language skills of early childhood. This is evidenced by the results of the teacher's assessment of children's language development from small group trials. The score is $80.83 \%$ with good criteria.

\section{ACKNOWLEDGEMENT}

This research was fully funded by the Muhammadiyah University of North Sumatra. Therefore, as a team, we would like to thank the Chancellor of the University of Muhammadiyah North Sumatra and his staff and do not forget to also thank the chairman of the Institute for Research and Community Service who has given us the opportunity to be able to carry out this research as a task for the Tri Dharma of Higher Education. through the APB Muhammadiyah University of North Sumatra in accordance with the Letter of Assignment Agreement for the Implementation of the Fundamental Research Program of the UMSU APB Fund for the 2021 Fiscal Year Number: 175/II.3-AU/UMSU-LP2M/C/2021. The researcher also thanks the Head of Kindergarten ABA 13 Helvetia Medan who has given permission to the team to conduct research and the teachers who have assisted researchers in carrying out the research. 


\section{REFERENCES}

Arsyad, Azhar. Media Pembelajaran. Jakarta: Rajagrafindo Persada., 2011.

Fadillah, Muhammad. Desain Pembelajaran P AUD. Yogyakarta: Ar-Ruzz Media, 2012.

Fauzi, Fauzi, Supa'at Supa'at, and Ifada Novikasari. 'Holistic-Integrative Eduaction System in an Islamic Kindergarten'. QIJIS (Qudus International Journal of Islamic Studies) 7, no. 2 (30 December 2019): 399. https://doi.org/10.21043/qijis.v7i2.6449.

Firasaty, Okda, and Henny Puji Astuti. 'The Creativity of Early Childhood Painting through Media Waste in Islamic Center Kindergarten Brebes'. BELIA: Early Childhood Education Papers 6, no. 2 (2017): 98-102.

Kiromi, Ivonne Hafidlatil, and Puji Yanti Fauziah. 'Jurnal Pendidikan Dan Pemberdayaan Masyarakat Camatan Tolangohula Kabupaten Gorontalo'. Jurnal Pendidikan Dan Pemberdayaan Masyarakat 3, no. 4 (2016): 38-47.

Masitah, Widya, and Juli Hastuti. 'Meningkatkan Kemampuan Bahasa Melalui Metode Bercerita Dengan Menggunakan Media Audio Visual Di Kelompok B RA Saidi Turi Kecamatan Pancur Batu Kabupaten Deli Serdang. Intiqad: Jurnal Agama Dan Pendidikan Islam 8, no. 2 (2016): 120-46. https://doi.org/10.30596/intiqad.v8i2.733.

Nurbety, Eka, and Yuli Kurniawati Sugiyo Pranoto. 'Relationship Between Self Regulation with Self-Esteem of Early Childhood in Kindergarten Islamic Integrated Bina Amal Semarang City'. BELLA: Early Childhood Education Papers 7, no. 1 (2018): 26-31.

Oleh Nita Nurcahyani WS, Elizabeth Prima, Putu Indah Lestari. 'Kata Bergambar Pada Anak Kelompok B'. Meningkatkan Kemampuan Berbahasa Anak Usia Dini Melalui Permainan Menjepit Kartu Kata Bergambar Pada Anak Kelompok 1, no. 1 (2016): 48.

Rahma, Fatikh Inayahtur. '(Kajian Terhadap Langkah-Langkah Pemilihan Media Dan Implementasinya Dalam Pembelajaran Bagi Anak Sekolah Dasar)'. Jurnal Studi Islam 14, no. 2 (2019): 87-99.

Siregar, Alfitriani, Ratna Sari Dewi, and Rita Harisma. 'Pengajaran Anak Usia Dini Melalui Buku Flanel Terintegrasi Dalam Bahasa Inggris'. Paramasastra 5, no. 1 (2018). https://doi.org/10.26740/parama.v5i1.2731.

Sitepu, Juli Maini, and Mawaddah Nasution. 'Kreativitas Pembuatan Media Pembelajaran Big Book Pada Guru-Guru RA Di Kecamatan Medan Maimun'. JURNAL PRODIKMAS Hasil Pengabdian Kepada Masyarakat 3, no. 1 (2018): 8-16.

Sugiyono. Metode Penelitian Pendidikan Pendekatan Kuantitatif Kualitatif Dan R\&D. Bandung: Alfabeta, 2014.

Tomkins, G.E \& Hoskisson, K. Language Arts Content Teaching Strategies. USA: Prentice Hall, Inc, 1995.

Widya Masitah. 'Pembuatan Media Pembelajaran Melalui Seni Decaupage Pada Guru Raudhatul Athfal Kecamatan Medan Area' 2, no. 2 (2018).

Zahro, Indah Fajrotuz. 'Meningkatkan Perilaku Prososial Anak Dengan Teknik Islamic Storytelling Finger Doll'. Nazhruna: Jurnal Pendidikan Islam 1, no. 1 (16 August 2018): 80-95. https://doi.org/10.31538/nzh.v1i1.43. 